V. F. Prykhodchenko ${ }^{1}$, Dr. Sc. (Geol.), Prof., orcid.org/0000-0002-7658-8758,

N. V. Khomenko', orcid.org/0000-0003-1509-3054,

M.V.Zhykalyak², Cand. Sc. (Geol.), Dr. Sc. (Econ.), D. V. Prykhodchenko ${ }^{1}$, Cand. Sc. (Geol.), Assoc. Prof., orcid.org/0000-0003-3035-5702,

L. O. Tokar' ${ }^{1}$, orcid.org/0000-0002-9448-5883
1 - Dnipro University of Technology, Dnipro, Ukraine, e-mail: pvfpvf@meta.ua

2 - State Regional Geological Enterprise "Donetskheolohiia" of the State Service of Geology and Mineral Resources of Ukraine, Bakhmut, Ukraine, e-mail: dongeo@ukr.net

\title{
INFLUENCE OF LOCAL OROGENY AND RESERVOIR CHARACTERISTICS OF ENCLOSING ROCKS ON THE LOCATION OF GAS TRAPS WITHIN THE COAL BEARING DEPOSITS
}

Purpose. To determine the nature of the effect of different-type local structures as well as reservoir characteristics of enclosing rocks in the location of gas traps within the coal bearing deposits of Pavlohrad-Petropavlivka and Krasnoarmiisk geological and industrial Donbas regions.

Methodology. Analysis and classification of geological stock and published scientific sources. Developing and analyzing maps characterizing location of methane traps within coal bearing formation followed by the analysis of traps.

Findings. Connection between location of positive methane bearing anomalies and free methane content within coal seams, and local plicative structures has been identified. The anomalies are connected with structures of both anticlinal and synclinal types. Difference in reservoir characteristics of roof rocks of coal seams within areas under study makes it possible to believe that argillites and aleurites of Krasnoarmiisk district are almost impermeable. If they occur in roof of local folds, they will favour methane conservation. In the context of Pavlohrad-Petropavlivka district, significant permeability of argillite and aleurites results in the fact that they cannot be a shield for folds; it concerns especially gentle folds where fractured zone is formed within arching. Rocks of upper share of a fold may become shield in local synclinal structures.

Originality. It has been proved for the first time that in the neighborhood of anticlinal local structures, synclinal local structures of coal seams may have methane accumulations if impermeable rocks are available within the synclinal roof.

Practical value. The determined regularities will help to enhance prognostic reliability of methane accumulations within the coal deposits.

Keywords: methane bearing, reservoir characteristics, local orogeny, permeability, methane accumulation

Introduction. According to the expert opinion, resource methane potential of coal deposits in Ukraine is 3-4 times more than natural gas reserves. In the context of Donetsk coal field, methane content of coal varies from 5 to $45 \mathrm{~m}^{3} / \mathrm{t}$ of d.a.f.; estimated methane reserves are 450-500 million $\mathrm{m}^{3}$ down to $1800 \mathrm{~m}$; and enclosing rocks contain up to $1.5-2$ trillion $\mathrm{m}^{3}$ of methane [1]. Commercial methane extraction from coal deposits and its recovery would help satisfy partially national demand for energy carriers. Efficient methane extraction from coal deposits depends upon its expansion and accumulation in coal bearing formation, and possibility to identify local methane accumulations within coal seams [2, 3].

Literature review. It is known that in coal seams, methane may be either free or occluded; share of the former is not more than $10 \%$. Free gas fills coal pores and fractures; the amount depends upon its reservoir characteristics, formation pressure, and rock mass temperature. Greater share of coal methane is occluded: in the form of solution in a solid matter (i.e. absorbed), in the form of condensate at the surface of pores (i.e. adsorbed), and in the form of condensate in supermolecular pores resulting from metamorphism.

According to the conditions of gas trap formation within the coal bearing deposits, the three basic types of reservoirs are separated: porous, fracture, and mixed. Porous reservoirs are rocks within which intergranular pores are interconnected by means of pore channels; their pore space is $40-50 \%$, and permeability is $0.1 \cdot 10^{-15}-\mathrm{n} \cdot 10^{-15} \mathrm{~m}^{2}$. Fracture reservoir permeability depends heavily upon open fissures; like in porous reservoirs, a capacity is stipulated by primary intergranular space and secondary cavities, caverns, and opens. Fracture poriness is not more than $3.0 \%$, and total volume of fracture pores and

(C) Prykhodchenko V.F., Khomenko N.V., Zhykalyak M. V., Prykhodchenko D. V, Tokar L. O., 2019 intergranular pores is $5-7 \%$. The reservoirs are characterized by low poriness and wide range of permeability variation (i.e. $10^{-17}$ to $10^{-7} \mathrm{~m}^{2}$ ). Generic difference of the reservoir types is as follows: fracture reservoir rocks become both trap and reservoir in the process of folding; moreover, formation of morphological traps is followed by a formation of reservoir rock in it (i.e. secondary rock changes in the fractured area specifying their capacitive and filtrational characteristics). Hence, fractured reservoirs originate either simultaneously with a trap or later. Mixed reservoir type combines intergranular pores, and fractured pores originating in deep rocks $[4,5]$.

In the context of the fractured type, capacitive characteristics, and filtrational ones are determined with the help of fissures (i.e. permeability, being more than $10^{-15} \mathrm{~m}^{2}$ when porosity is less than $3 \%$ ). In the context of porous and fractured reservoirs, capacities of fissures and matrix are almost similar (i. e. fissure porosity is $1-3 \%$, and porous channels are $3-6 \%$ ) and filtration comes along fissures whose permeability is more than $10^{-15} \mathrm{~m}^{2}$. In the context of fractured and porous reservoirs, matrix capacity (more than $6 \%$ ) prevails fracture capacity; thus, filtration comes along pores and fissures which permeability is not less than $10^{-16} \mathrm{~m}^{2}$.

Stratigraphic traps, structural traps, tectonic traps, lithological traps, and hydrodynamical traps are common in coal bearing deposits $[6,7]$. Practices, analyzing effect of geological structures on methane content of coal seams, prove that the main share of the gas, being a part of coal bearing formation, is accumulated within the anticlinal, and brachyanticlinal structures as well as within the areas of monocline-shaped displacements; moreover, their majority is concentrated within the arching shares of the structures $[8,9]$. The fact can be explained by nonuniformity of the coal bearing formation when seams differ in their composition and structure as well as in their deformational characteristics. Common deformation 
of bedded rock mass factors into solid layer fracturing; in the context of the softer layers, it factors into plastic deformations. Formation of any geological structure is followed by a progress of macro- and micro-fissures as well as increased capacity of rocks and their permeability within the areas of the greatest tectonic deformation $[10,11]$.Tectonic faults are followed by the formation of fissure systems which may be either reservoirs of gas conductors to reservoir rocks and coal grinding into loose mass favours sorbed gas emission.

Lukinov V.V. [12] proposed a model to form fractured and porous reservoir in sandstones when rocks are bending to anticlinal fold. Thus, if seams stretch from the floor to the roof, their fissuring increases; moreover, within the lower sandstone share, where stretching deformations do not achieve marginal values, the fissures are out of their progress to compare with fissures progressing within the upper share. The fact improves filtration indices of the sandstone; owing to the increased fissure permeability, methane transforms to a free state having ability to accumulate in the form of a deposit. The same sandstone is the deposit shield; the sandstone becomes flatter updip with no suffering from fissures in virtue of lesser bend thus becoming gas tight. Similar mechanism of reservoir origination is also possible under the conditions of formation of synclinal bends.

Unsolved aspects of the problem. Significant gas amounts were extracted during degassing well drilling within the arch of a synclinal structure of Donetsk-Makiivka district where methane debit was 3.6 thousand $\mathrm{m}^{3} /$ day. We have recorded the increased indices of gas content and free methane content within the synclinal bends in Krasnoarmiisk district. Within the mine fields of Pavlohrad-Petropavlivka district, extra anomalies of gas and free methane were also identified in arches and wings of local synclinal structures.

Purpose. It is necessary to determine a nature of local orogeny and lithological composition of enclosing rocks on the location of gas traps within the coal bearing deposits of Pavlohrad-Petropavlivka and Krasnoarmiisk geological and industrial areas.

Description of the methods. To solve the problem, geologicalstock scientific sources and goal-oriented ones were analyzed and generalized. Maps of surfaces of coal seams and maps of gas content measurements of coal seams by means of gas sample collector KA-61 were plotted. Lithological maps of roof of coal seams of the objects under study were analyzed. Logic and analytical method was applied to analyze the plotted maps; basic regularities of location of methane anomalies were determined. Systematization of materials of geological stocks as well as the published purpose-oriented papers made it possible to compare reservoir characteristics of enclosing rocks and identify their difference and nature of the effect on methane conservation within the local structures.

Results. Mines of the districts extract bituminous coal of metamorphic stage 2 [12] of the Mississippian period, Lower Carbonic period, and Middle Carbonic period. Structure of the districts and their coal content are characterized by a low degree of catagenetic transformationsof rocks having high poriness and permeability. Regional dislocation is minor; both of the districts are monoclinal with flat plicative structures, whose structures are up to hundreds of meters, and fault tectonics of different degrees. Orogeny is represented by domelike and brachiformal structures of anticlinal and synclinal types; moreover, it is connected with tectonic faults. Anomalies, formed within the arching shares of positive and negative plicative structures and faults, are of the keen interest for analysis. Within the areas, where the structures bend, zones of fissured rocks arise in reservoirs in addition to porous and fissured traps with new capacitive and filtration characteristics.

Consider nonuniformity of local methane anomalies in terms of coal seam c $c_{4}$ in Samarska mine (Pavlohrad-Petropavlivka district) [13]. Thus, a map of local methane-content structures, overlapped with local hypsometry structures, demonstrates (Fig. 1) that positive south-western anomaly has

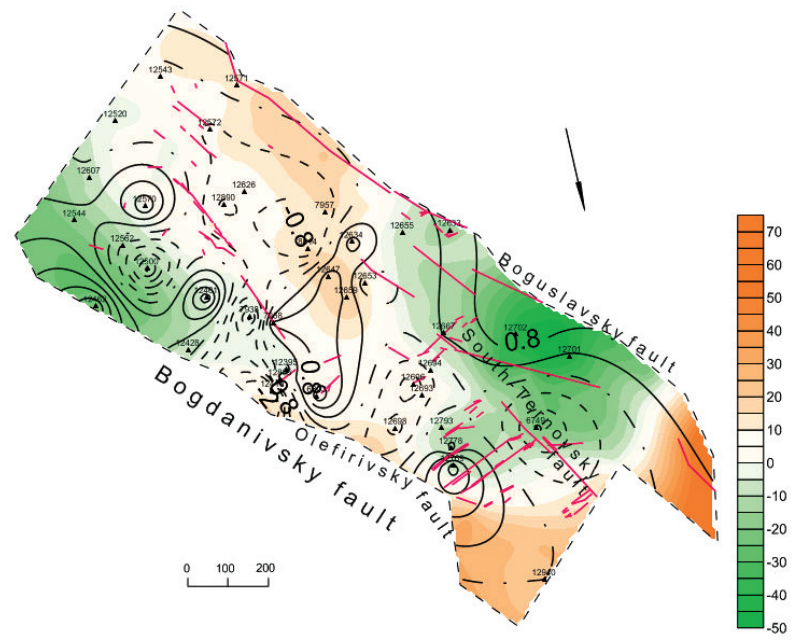

Fig. 1. Local structures and anomalies of methane content of coal seam $c_{4}$ in Samarska mine, and fault tectonics: $-2-$ positive anomalies of methane content; $C_{2}-$ negative
anomalies of methane content; - fault tectonics

been formed within the arching share of synclinal bend in the neighborhood of Bohuslavskyi fault and the north-eastern one is within the action of Olefirivskyi fault in a wing of a synclinal bend stretching to anticlinal bend.

The north extended central one coincides with the anticlinal bend being observed within the central share of the mine field as well as within its south-eastern share. Eastern one coincides with a local synclinal structure along Bohdanivskyi fault. The largest negative methane anomaly stretches north occupying a flat wing of anticlinal bend; its intensity increases in the neighborhood of Bohdanivskyi fault. Lesser negative anomaly also adjoins high-amplitude and is located within the anticlinal bend. Two negative anomalies (i.e. eastern and western) are connected with synclinal structures; the latter is disturbed by Pivdenno-Ternivskyi fault. Immediate roof of coal seam $\mathrm{c}_{4}$ of the mine consists mainly of aleurites and argillites alternating each other regularly in the form of elongated irregular spots oriented north-east south-westwardly. Average thickness of argillites is $5.6 \mathrm{~m}$; average thickness of aleurites is $9.5 \mathrm{~m}$; sandstones are recorded south-east within an area of tectonic faults (apophyses No.3, and No.4). Their thickness is $4.2 \mathrm{~m}$.

Hence, positive methane anomalies are connected with: synclinal structure associating Bohdanivskyi fault; synclinal bend within a wing of Bohuslavskyi fault; and a zone, disturbed by a series of low-amplitude faults in the neighborhood of Olefirivskyi fault. Large-area positive anomaly is in a flat wing of anticlinal structure within central share of a mine field. Roof of the seam consists of aleurite-argillite interbedding.

Methane content of coal seam $c_{1}$ in Pavlohradska mine is the example of the fact that local anticlinal structures degas coal seams. Large negative methane anomaly within the area coincides with anticlinal structure in the central share of the mine field. Positive north-east anomaly has been formed in a synclinal bend near Bohdanivskyi fault; another one, southwestern, is within a synclinal bend wing along Pivdenno-Ternivskyi fault. The roof of coal seam $c_{1}$ consists mainly of aleurites and sandstones. The largest thickness of the sandstones, being up to $5 \mathrm{~m}$, has been recorded within the central share of the field in anticline structure. Positive anomalies are within the synclinal bends stretching along the faults.

A map of local deviations as for free methane content within Zakhidnodonbaska mine in terms of seam $c_{8}^{b}$ demonstrates the same regularity (Fig. 2).

Intensive positive anomaly of free methane content is located in synclinal bend, associating Bohdanivskyi fault, and in 


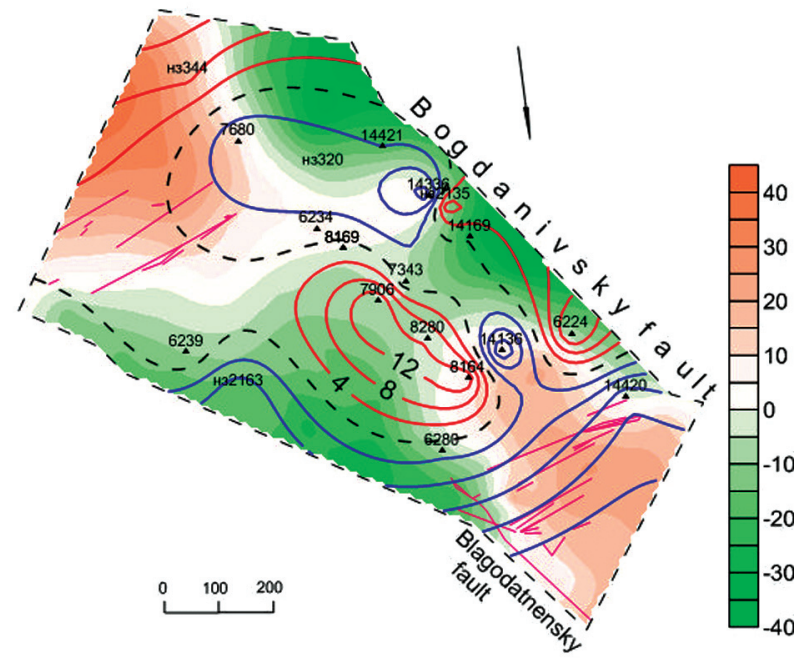

Fig. 2. Local structures and free methane content of coal seam $c_{8}^{b}$ In Zakhidnodonbaska mine (specifications in Fig. 1)

a central share within a flat wing of the synclinal structure Negative local deviations of free methane are within the northern share of the field in the arching of anticlinal bend, disturbed by a series of low-amplitude faults, in the synclinal bend along the mine field and along Blahodatnenskyi fault, and in the south of the mine field between synclinal bends within a wing of Bohdanivskyi fault [14]. Thus, free methane content increases within the synclinal bend near Bohdanivskyi fault as well within the synclinal structure in the central share of the mine field.

The roof of coal seam c8B consists mainly of aleurites (up to $60 \%)$, argillites $(20 \%)$, and sandstones (20\%). Average thickness of the aleurites is $8.8 \mathrm{~m}$; the largest thickness, being $16.65 \mathrm{~m}$, has been recorded within the local synclinal bend in the northern share of the mine field. Argillites and sandstones are represented in the form of separate spots with up to $4.3 \mathrm{~m}$ average thickness.

Taking all the aforesaid into consideration, it is possible to note that in the context of Pavlohrad-Petropavlivka district, positive methane anomalies associate with local synclinals; as for the anticlinals, sometimes positive anomalies associate but negative ones associate more often.

Two anticlinal folded structures and two synclinal ones are singled out in the map of local deviations of hypsometry of seam $l_{3}$ in Biletska mine (Krasnoarmiisk geological and industrial area). Positive methane anomalies are within the northeast share of a synclinal structure formed in the neighborhood of Dobropilskyi overlap fault. It stretches east within the central share of the field in a synclinal structure and in the arching of anticlinal local fold southward of the mine field. The largest positive anomaly occupies central share of the mine field and is located within the local synclinal structure.

Local deviations of free methane content of seam $l_{3}$ in $\mathrm{Bi}$ letska mine are also closely connected with local folds. Increase in free methane content takes place southerly towards south synclinal bend. Negative indices are recorded within the synclinal bend in the neighborhood of Dobropilskyi overlap as well as within a wing of south-western anticlinal structure. Intensive anomaly of free methane content is within a local synclinal structure (Fig. 3). Increased free methane content within the seam coincides with north-western deepening of the coal bearing formation. Like anticlinal within the southern share, the synclinal within Dobropilskyi overlap is characterized by negative indices.

Aleurites (45\%) and argillites (40\%) with 2.6-19 m thickness prevail within the lithological rock composition of the seam roof; sandstones $(15 \%)$ are abundant within the northern share of the mine field.

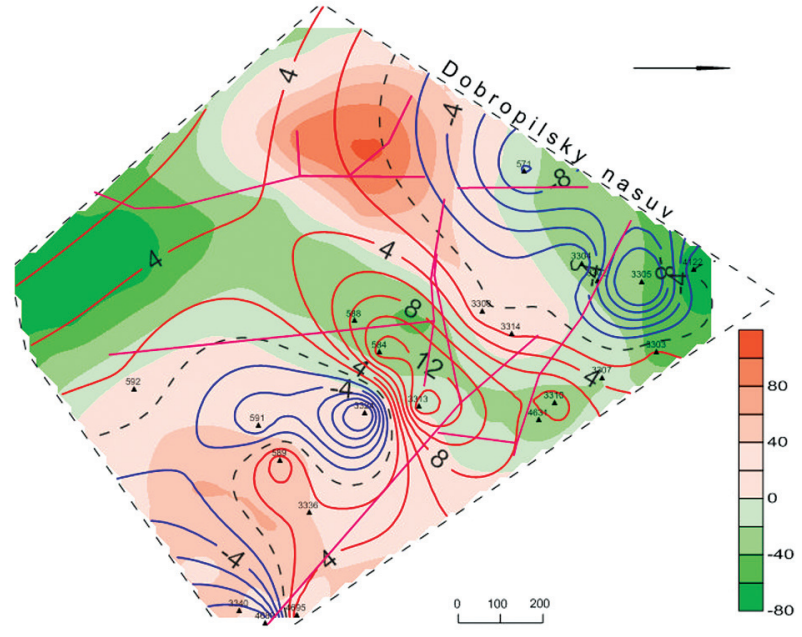

Fig. 3. Local structures of hypsometry and anomaly of local deviations as for free methane content of coal seam $l_{3}$ in $\mathrm{Bi}$ letska mine (specifications in Fig. 1)

Increased methane content indices have been identified within three structures of the mine. Two of them are connected with local synclinal structures; one of them is within a wing of high-amplitude Dobropilskyi overlap and the other one is between anticlinal bends in the center of the mine field. Anomaly three is in the southern anticlinal nose. Intensive anomaly of free methane is within the local synclinal structure. The increased free methane content coincides with north-eastern deepening of the coal bearing formation. Like southern anticlinal, the synclinal within a wing of Dobropilskyi overlap is characterized by negative indices. Aleurites $(45 \%)$ and argillites (40\%) prevail in a lithological composition of roof rocks. Their thickness varies from 2.6 to $19 \mathrm{~m}$. Sandstones $(15 \%)$ are common in the north of the mine field.

The surface of local deviations of coal seam 13 in Dobropilska mine is a running one with clearly manifested flat anticlinal in the neighborhood of Dobropilskyi overlap and two synclinal bends within the northern and north-western shares in the course of the anticlinal. Intensive positive gas anomaly is in the northern share of the mine field coinciding with the synclinal structure location. Negative anomalies are connected with Dobropilskyi overlap and with areas of low-amplitude faults. Free methane deviations within the mine field are positive essentially; three of them are between faults within the local synclinal structure. The fourth one coincides with an area of low-amplitude fissures. Negative anomalies are connected with a flat anticlinal along Dobropilskyi overlap and area of low-amplitude disturbance. Thus, positive methane anomalies often refer to local synclinal and anticlinal structures.

Argillites (60\%) prevail among roof rocks; aleurites $(25 \%)$ and sandstones $(15 \%)$ prevail within the northern and central shares. In this context, thickness of argillite-aleurite formation varies from 1.2 to $5.2 \mathrm{~m}$

Summing up the analysis of local orogeny effect on the formation of methane traps within the coal-bearing deposits of the regions has helped determine the following:

1. The increased indices of methane and free methane are recorded both in synclinal and anticlinal local structures of the regions.

2. Positive methane anomalies of Pavlohrad-Petropavlivka geological and industrial region are concentrated mainly within the local synclinal structures associating such faults as Bohdanivskyi and Pivdenno-Ternivskyi. Most of all, methane values are connected with the anticlinal structures and areas of low-amplitude disturbances. Hence, positive methane anomalies are formed within the local synclinals; sometimes, positive anomalies (and more often negative anomalies) are formed within the anticlinals. 
3. In the context of the mentioned mines of Krasnoarmiisk geological and industrial area, local structures of the both types, located along Dobropilskyi overlap, are characterized by negative methane indices. Positive anomalies are not connected with tectonic faults; they are concentrated in synclinal structures. Positive anomalies also occur; they are connected with the local anticlinal structures.

Consider the nature of the effect of reservoir characteristics of lithological composition of enclosing rocks on the location of gas traps within the coal deposits. Mines of the regions extract bituminous coal of Low Carbonic period (Pavlohrad geological and industrial area) and Middle Carbonic period (Krasnoarmiisk geological and industrial area).

Argillites, aleurites, and fewer sandstones prevail in lithological composition of rocks enclosing coal seams in Pavlohrad-Petropavlivka district. The roof of coal seams is represented by argillites $(50 \%)$, aleurites $(41 \%)$, and sandstones (up to $9 \%$ ). Coal-bearing formation of Krasnoarmiisk district is represented by layering of sandstones, aleurites, argillites, limestones, and coal seams. Lithologically, argillites and aleurites prevail (up to $70 \%$ ); sandstones are up to $25 \%$, and limestones are up to $4 \%$. According to the data from papers [4, 15], permeability of rocks of Low Carbonic period and Middle Carbonic period differs greatly (Table).

It should be noted that average permeability of sandstones is similar. Permeability of argillites and aleurites, being a majority of coal bearing formation (i.e. 70-91\%), differs greatly. In the context of Krasnoarmiisk district, the rocks are almost impermeable $\left(0.001 \cdot 10^{-15} \mathrm{~m}^{2}\right)$; in the context of PavlohradPetropavlivka district, their permeability is almost by two orders of magnitude more (i. e. $0.112-0.495 \cdot 10^{-15} \mathrm{~m}^{2}$ ). The fact effects gas conservation in local structures.

In the context of synclinal structures, fissured zones are formed in the floors of coal seam; the coal seam itself is a shield for methane migration. Consequently, local synclinals are of positive indices predominantly as well as methane and free methane content in the two regions under study.

In the general case, formation of fissured and porous space within the anticlinal arching results in the formation degassing. Principally, local anticlinal bends have negative indices (for instance, Pavlohrad district). In the context of Krasnoarmiisk district, positive anomalies of both methane content and free methane content are also connected with positive anomalies. That can be explained by the fact that argillites and aleurites, making a roof of coal seams, form impermeable shield which conserves gas in its trap.

Conclusions. Relation between the location of positive methane anomalies and free methane content within the coal seams with local plicative structures has been determined. Location of methane anomalies and free methane content in coal seams is connected with the structures of both anticlinal and synclinal types. Formation of fissured and porous space within the arching of such structures results either in degassing or in origination of local methane traps depending upon the reser-

Table

Reservoir characteristics of enclosing rocks

\begin{tabular}{|l|c|c|c|c|}
\hline \multirow{2}{*}{} & \multicolumn{2}{|c|}{$\begin{array}{c}\text { Pavlohrad-Petropavlivka } \\
\text { district }\end{array}$} & \multicolumn{2}{c|}{$\begin{array}{c}\text { Krasnoarmiisk } \\
\text { district }\end{array}$} \\
\cline { 2 - 5 } & $\begin{array}{c}\text { Total } \\
\text { porosity, } \%\end{array}$ & $\begin{array}{c}\text { Permeability, } \\
n \cdot 10^{-15} \mathrm{~m}^{2}\end{array}$ & $\begin{array}{c}\text { Total } \\
\text { porosity, \% }\end{array}$ & $\begin{array}{c}\text { Permeability, } \\
n \cdot 10^{-15} \mathrm{~m}^{2}\end{array}$ \\
\hline Sandstones & $\frac{1.1-35.7}{16.6}$ & $\frac{0.382-7.708}{0.823}$ & $\frac{3.0-26.5}{8.5}$ & $\frac{0.01-47.47}{0.766}$ \\
\hline Aleurolites & $\frac{1.6-39.9}{12.41}$ & $\frac{0.004-7.974}{0.495}$ & $\frac{1.0-17.8}{6}$ & 0.001 \\
\hline Argillites & $\frac{0.4-33.4}{11.7}$ & $\frac{0.003-1.707}{0.112}$ & $\frac{0.7-11.5}{5}$ & 0.001 \\
\hline
\end{tabular}

voir characteristics of rocks of impermeable seams. Aleurite and argillite permeability of the two districts differs greatly. Argillite and aleurite of Krasnoarmiisk district are almost impermeable. If they occur within the roof of local folds they are shields anyway. In the context of Pavlohrad-Petropavlivka district, significant permeability of argillites and aleurites results in the fact that they cannot always be shield for folds; it especially concerns anticlinals in which arching fissured area is formed. In the context of local synclinal structures, rocks of the upper share of a fold, where certain densification has taken place, may become shields. That is why, most anomalies of methane and free methane content in Pavlohrad-Petropavlivka region are connected with the synclinal structures. The determined regularities will help improve reliability of methane accumulation forecast within the coal deposits.

\section{References.}

1. Lukinov, V.V., Bezruchko, K.A., Prikhodchenko, O. V., \& Shpak, V.Yu. (2012). Estimation of promising areas with the aim of methane accumulations exploration (on the example of mine Butovska). Naukovyi Visnyk Natsionalnoho Hirnychoho Universytetu, 2, 27-35.

2. Ivanova, A. V., \& Zaitseva, L. B. (2018). Gas-bearing capacity factors of the Lower Carbon deposits in Western Donbas (on the example of Pavlograd-Petropavlovsk coal region). Naftohazova haluz Ukrainy, (5), 14-19.

3. Zhykaliak, N. V., Shaidorova, I. M., \& Sverbikhin, Yu. G. (2012). Mining and geological conditions for the extraction of methane gas from coal deposits and mines in Western Donbass. Geo-technical mechanics, (102), 93-102.

4. Bulat, A. F., Lukinov, V.V., \& Bezruchko, K.A. (2017). Conditions for gas trap formation in coal-bearing strata. Kyiv: Naukova dumka.

5. Lukinov, V., Prykhodchenko, V., Tokar, L., \& Prykhodchenko, O. (2014). Mining and geological conditions of methane redistributions within the undermining coal-rock massif. Progressive Technologies of Coal, Coalbed Methane, and Ores Mining, 317-325. DOI: 10.1201/b17547.

6. Pluzhnikova, V. L., \& Verhelska, N. V. (2015). Structuraltectonic factor of formation of gas-bearing capacity of Donbass coal masses. Mineralni resursy Ukrainy, (4), 22-25.

7. State Committee of Ukraine for Mineral Reserves. (2008). Instruction on the application of the State Subsoil Fund Classification of Reserves and Resources of Minerals to the geological and economic assessment of the total (emissive) and mining reserves of coal bed methane of coal and gas deposits in areas of associated technologically necessary degassing during the development of coal seams. Retrieved from https://zakon.rada.gov. ua/laws/show/z0007-09].

8. Bezruchko, K.A., Diachenko, N., \& Urazka, M. (2018). Influence of the Western Donbas share dislocation zone on the formation of gas accumulations in coal-bearing sediments. Heodynamika, 1(24), 27-39. DOI: 10.23939/jgd2018.01.027.

9. Pryvalov, V. A., Panova, O. A., \& Sachsenhofer, R. F. (2013). Natural Fracture and Cleat Patterns in Coalbed and Shale Gas Reservoirs of the Donets Basin (Ukraine). $75^{\text {th }}$ European Association of Geoscientists and Engineers Conference and Exhibition 2013 Incorporating SPE EUROPEC 2013: Changing Frontiers, (pp. 3607-3612). DOI: 10.3997/2214-4609.20130809.

10. Bezruchko, K., Prykhodchenko, O., \& Tokar, L. (2014). Prognosis for free methane traps of structural and tectonic type in Donbas. In Progressive Technologies of Coal, Coalbad Methane, Ores Mining. London: Taylor \& Francis Group, 267-271. 11. Verhelska, N.V., Skopychenko, I. M., \& Yevdoshchuk, M. I. (2019). Formation features of gas deposits of coal basins. Actual problems and perspectives of geology: science and industry (Geoforum-2019) (pp. 42-45). Odesa, Ukraine: UkrDGRI. Retrieved from http://ukrdgri.gov.ua/wp-content/uploads/2019/06/ material_geoforum_2019_1.pdf.

12. Lukinov, V., Prykhodchenko, A., Prykhodchenko, V., \& Tykhonenko, O. (2018). Changes in Density of Carbon Ato- 
mic Packing in Natural Formations. Solid State Phenomena, (277), 202-212.

13. Volkova, T. I., Alekhin, V. I., \& Silin, A. A. (2011). Identification of local gas-bearing structures by the trend analysis method. Ugol Ukrainyi, (5), 33-36.

14. Prykhodchenko, V.F., Sdvyzhkova, O.O., Khomenko, N. V., \& Tykhonenko, V. V. (2016). Effect of time-transgressive faults upon methane distribution within coal seams. Naukovyi Visnyk Natsionalnoho Hirnychoho Universytetu, 1, 31-35.

15. Antsyferov, A.V., Holubev, A.A., Kanyn, V.A., Tirkel, M.G., Zadara, G. Z., Uziiuk, V. I., Antsyferov, V.A., \& Suiarko, V.G. (2009). Gas content and methane resources of coal basins of Ukraine: [monograph]; in 3 volumes. Vol.1: Geology and gas content of Western, Southwestern and Southern Donbass. Donetsk: Veber.

\section{Вплив локальної складчастості й колекторських властивостей вміщуючих порід на розміщення газових пасток у вугленосних відкладах}

В. Ф. Приходиенко ${ }^{1}$, Н. В. Хоменко ${ }^{1}$, М. В. Жикаляк ${ }^{2}$ Д. В. Приходченко ${ }^{1}$, Л. О. Токар ${ }^{1}$

1 - Національний технічний університет „Дніпровська політехніка“, м. Дніпро, Україна, e-mail: pvfpvf@meta.ua 2 - ДРГП „Донецькгеологія”, м. Бахмут, Україна, e-mail: dongeo@ukr.net

Мета. Визначити характер впливу локальних структур різних типів і колекторських властивостей вміщуючих порід на розміщення газових пасток у вугленосних відкладах Павлоградсько-Петропавлівського та Красноармійського геологопромислових районів Донбасу.

Методика. Аналіз і систематизація геологічної фондової та опублікованої спеціальної літератури. Побудова та аналіз спеціальних карт, що характеризують розміщення пасток метану у вугленосній товщі, їх аналіз.

Результати. Встановлено зв'язок між розміщенням позитивних аномалій метаноносності та вмісту вільного метану у вугільних пластах з локальними плікативними структурами. Аномалії пов'язані зі структурами як антиклінального, так і синклінального типів. Відмінність колекторських властивостей порід покрівлі вугільних пластів у районах дослідження дає підстави вважати аргіліти та алевроліти Красноармійського району практично непроникними. У разі їх розташування в покрівлі локальних складок вони будуть сприяти збереженню метану. У Павлоградсько-Петропавлівському районі суттєва проникність аргілітів і алевролітів призводить до того, що вони не завжди можуть відігравати роль екранів для складок, особливо для антикліналей, де у склепінні утворюється зона тріщинуватості. У локальних синклінальних структурах екранами можуть бути породи верхньої частини складки.

Наукова новизна. Доведено, що синклінальні локальні структури вугільних пластів поряд з антиклінальними можуть вміщувати скупчення метану, навіть за наявності в покрівлі синкліналі проникних порід.
Практична значимість. Встановлені закономірності дозволять підвищити достовірність прогнозу скупчень метану в межах вугільних родовищ.

Ключові слова: метаноносність, колекторські властивості, локальна складчастість, проникність, скупчення метану

\section{Влияние локальной складчатости и коллекторских свойств вмещающих пород на размещение газовых ловушек в угленосных отложениях}

\author{
В. Ф. Приходиенко ${ }^{1}$, Н. В. Хоменко, Н. В. Жикаляк ${ }^{2}$, \\ Д. В. Приходченко ${ }^{1}$, Л.А. Токар ${ }^{1}$
}

1 - Национальный технический университет „Днепровская политехника“, г. Днепр, Украина, e-mail: pvfpvf@ meta.ua

2 - ГРГП „Донецкгеология”, г. Бахмут, Украина, e-mail: dongeo@ukr.net

Цель. Определить характер влияния коллекторских свойств вмещающих пород и типа локальных структур на размещение газовых ловушек в угленосных отложениях Павлоградско-Петропавловского и Красноармейского геологопромышленных районов Донбасса.

Методика. Анализ, систематизация геологической фондовой и опубликованной специальной литературы. Построение и анализ карт, характеризующих размещение ловушек метана в угольной толще, их анализ.

Результаты. Выявлена связь размещения положительных аномалий метаноносности и содержания свободного метана с локальными пликативными структурами как антиклинального, так и синклинального типов. Отличия коллекторских свойства пород кровли угольных пластов в районах исследования позволяют утверждать, что аргиллиты и алевролиты Красноармейского района являются практически не проницаемыми. В случае размещения их в кровле локальных складок они будут способствовать сохранению метана. Значительная проницаемость аргиллитов и алевролитов в Павлоградско-Петропавловском районе приводит к тому, что своды антиклиналей, где и так образуются зоны трещиноватости, дегазируются, а локальные синклинальные структуры будут способствовать сохранению метана за счет уплотнения пород верхней части складки.

Научная новизна. Доказано, что синклинальные локальные структуры в угольных пластах, так же как и антиклинальные, могут содержать скопления метана, даже при наличии в кровле синклиналей проницаемых пород.

Практическая значимость. Выявленные закономерности позволят повысить достоверность прогноза скоплений метана в толщах угольных месторождений.

Ключевые слова: метаноносность, коллекторские свойства, локальная складчатость, проницаемость, скопления метана

Рекомендовано до публікації докт. техн. наук I. О. Садовенком. Дата надходження рукопису 21.01.19. 